\title{
Editorial
}

\section{Progress in Combustion Diagnostics, Science and Technology}

\author{
Paul Ross Medwell ${ }^{1, *}$, Michael John Evans ${ }^{1}{ }^{(\mathbb{D}}$ and Qing Nian Chan ${ }^{2}$ \\ 1 School of Mechanical Engineering, The University of Adelaide, Adelaide, SA 5005, Australia; \\ m.evans@adelaide.edu.au \\ 2 School of Mechanical and Manufacturing Engineering, The University of New South Wales, Sydney, \\ NSW 2052, Australia; qing.chan@unsw.edu.au \\ * Correspondence: paul.medwell@adelaide.edu.au
}

Received: 19 February 2020; Accepted: 24 February 2020; Published: 27 February 2020

The role that combustion plays in energy systems remains crucial in supplying the world's ever-increasing power demands. In the never-ending quest for improving efficiency, additional knowledge is essential to develop new combustion technologies and appliances. Increasingly, there is more focus on the conservation of energy and on addressing environmental concerns, which together, necessitate cleaner and more efficient combustion processes using a range of fuel sources. This is essential to respond to global challenges in energy supplies and to continue to address issues of the decarbonization of the sector. In addition to power production, understanding combustion also plays a critical role in both managing fires and in the material synthesis sectors. To meet the objectives of evolution and innovation in combustion science, new experimental measurements are needed and complemented by computational approaches.

This book includes a series of seventeen research studies that reveal new knowledge about combustion and its application. The topics covered span many diverse areas associated with combustion including: fires [1-3], engines and applications [4-15], and acoustics [16,17].

In combination, these complementary contributions provide a substantial body of knowledge in the field of Progress in Combustion Diagnostics, Science and Technology, hence the apt name of this exciting publication.

Author Contributions: All authors contributed equally to the preparation of this manuscript. All authors have read and agreed to the published version of the manuscript.

Funding: The financial support from the Australian Research Council through numerous grants and fellowships as part of the Discovery and Linkage programs is gratefully acknowledged.

Acknowledgments: This publication was only possible with the invaluable contributions from the authors, reviewers, and the editorial team of Applied Sciences.

Conflicts of Interest: The authors declare no conflict of interest.

\section{References}

1. Wang, C.; Yuen, A.; Chan, Q.; Chen, T.; Yip, H.; Cheung, S.; Kook, S.; Yeoh, G. Numerical Study of the Comparison of Symmetrical and Asymmetrical Eddy-Generation Scheme on the Fire Whirl Formulation and Evolution. Appl. Sci. 2020, 10, 318. [CrossRef]

2. Li, A.; Yuen, A.; Chen, T.; Wang, C.; Liu, H.; Cao, R.; Yang, W.; Yeoh, G.; Timchenko, V. Computational Study of Wet Steam Flow to Optimize Steam Ejector Efficiency for Potential Fire Suppression Application. Appl. Sci. 2019, 9, 1486. [CrossRef]

3. Wang, C.; Yuen, A.; Chan, Q.; Chen, T.; Chen, Q.; Cao, R.; Yip, H.; Kook, S.; Yeoh, G. Influence of Eddy-Generation Mechanism on the Characteristic of On-Source Fire Whirl. Appl. Sci. 2019, 9, 3989. [CrossRef] 
4. Jang, H.; Choi, D. Similarity Analysis for Time Series-Based 2D Temperature Measurement of Engine Exhaust Gas in TDLAT. Appl. Sci. 2020, 10, 285. [CrossRef]

5. Longwic, R.; Sander, P.; Zdziennicka, A.; Szymczyk, K.; Jańczuk, B. Combustion Process of Canola Oil and n-Hexane Mixtures in Dynamic Diesel Engine Operating Conditions. Appl. Sci. 2020, 10, 80. [CrossRef]

6. Eliasz, J.; Osipowicz, T.; Abramek, K.; Mozga, Ł. Model Issues Regarding Modification of Fuel Injector Components to Improve the Injection Parameters of a Modern Compression Ignition Engine Powered by Biofuel. Appl. Sci. 2019, 9, 5479. [CrossRef]

7. Zheng, H.; Liu, S.; Zhao, N.; Chen, X.; Jia, X.; Li, Z. Numerical Simulation of Hot Jet Detonation with Different Ignition Positions. Appl. Sci. 2019, 9, 4607. [CrossRef]

8. Han, Y.; Guo, L.; Wang, X.; Yuen, A.; Li, C.; Cao, R.; Liu, H.; Chen, T.; Tu, J.; Yeoh, G. A Steam Ejector Refrigeration System Powered by Engine Combustion Waste Heat: Part 1. Characterization of the Internal Flow Structure. Appl. Sci. 2019, 9, 4275. [CrossRef]

9. Han, Y.; Wang, X.; Guo, L.; Yuen, A.; Liu, H.; Cao, R.; Wang, C.; Li, C.; Tu, J.; Yeoh, G. A Steam Ejector Refrigeration System Powered by Engine Combustion Waste Heat: Part 2. Understanding the Nature of the Shock Wave Structure. Appl. Sci. 2019, 9, 4435. [CrossRef]

10. Nishiyama, A.; Le, M.; Furui, T.; Ikeda, Y. Simultaneous In-Cylinder Flow Measurement and Flame Imaging in a Realistic Operating Engine Environment Using High-Speed PIV. Appl. Sci. 2019, 9, 2678. [CrossRef]

11. Dong, X.; Wang, B.; Yip, H.; Chan, Q. $\mathrm{CO}_{2}$ Emission of Electric and Gasoline Vehicles under Various Road Conditions for China, Japan, Europe and World Average-Prediction through Year 2040. Appl. Sci. 2019, 9, 2295. [CrossRef]

12. Nishiyama, A.; Le, M.; Furui, T.; Ikeda, Y. The Relationship between In-Cylinder Flow-Field near Spark Plug Areas, the Spark Behavior, and the Combustion Performance inside an Optical SI Engine. Appl. Sci. 2019, 9, 1545. [CrossRef]

13. Lou, Z.; Zhu, G. Review of Advancement in Variable Valve Actuation of Internal Combustion Engines. Appl. Sci. 2020, 10, 1216. [CrossRef]

14. Yip, H.; Srna, A.; Yuen, A.; Kook, S.; Taylor, R.; Yeoh, G.; Medwell, P.; Chan, Q. A Review of Hydrogen Direct Injection for Internal Combustion Engines: Towards Carbon-Free Combustion. Appl. Sci. 2019, 9, 4842. [CrossRef]

15. Resende, P.; Ayoobi, M.; Afonso, A. Numerical Investigations of Micro-Scale Diffusion Combustion: A Brief Review. Appl. Sci. 2019, 9, 3356. [CrossRef]

16. Du, J.; Chen, X.; Liu, L.; Liu, D.; Ma, X. Mechanism of Combustion Noise Influenced by Pilot Injection in PPCI Diesel Engines. Appl. Sci. 2019, 9, 1875. [CrossRef]

17. Deng, K.; Wang, M.; Shen, Z.; Hu, Y.; Zhong, Y. Effect of Different Acoustic Parameters on NOx Emissions of Partially Premixed Flame. Appl. Sci. 2019, 9, 1490. [CrossRef] 